\title{
Historical Narrative on Dissolution Technologies, the Journal
}

\author{
Vivian Gray \\ Managing Director, Dissolution Technologies, Hockessin, DE USA
}

e-mail:vagray@rcn.com

T his narrative starts with Cynthia Brown, the founder of Dissolution Technologies. In 1994 she had the idea to publish dissolution testing scientific information in a peer-reviewed journal of articles. The first issue in the summer of 1994 contained a Letter from the Editor (Cynthia Brown) that said "Welcome to the premier issue of Dissolution Technologies. Drawing upon my personal experience in the dissolution laboratory, I perceived a need for a targeted publication on the complexities of dissolution. Therefore, the overall objective of the publication is to keep the dissolution user ahead of the new developments in the field of dissolution while conveying useful information on the day-to-day issues concerning dissolution applications." Over the years, the mission of Dissolution Technologies has remained true to Cindy's vision, and I want to take this opportunity to thank Cindy for founding this publication as a service to the Dissolution community.

The website, www.dissolutiontech.com, became a permanent fixture in 1997; the present design is essentially the same as it was back then. A big advance in 2009 was the installation of the Google search engine on the home page for all the previous and current articles. Another very recent feature is the installation of Google Analytics, which should provide useful statistical information on the viewing of the website.

In 1999 the $Q$ and A section became a permanent feature with USP actively supporting the responses for this section. In 2010 a book based on this $\mathrm{Q}$ and $\mathrm{A}$ feature, called Dissolution Technologies, Questions and Answers, was published. Other books that have been published by Dissolution Technologies, Inc., are The Handbook of Dissolution Testing and Dissolution Theory, Methodology, and Testing. Both these books have, on occasion, been donated to attendees of outreach dissolution workshops sponsored by the AAPS In Vitro Release and Dissolution Testing Focus Group. These two books and the $\mathrm{Q}$ and $\mathrm{A}$ book are available for purchase on the website.

In 2003 Dissolution Technologies changed hands to my ownership, keeping the same Editorial Advisory Board and keeping Cindy as Editor, which is as it is today. There have been 16 additions to the Editorial Advisory Board for a total of 26 members (Table1). The increase in Board members was needed to keep up with the reviews of submitted manuscripts. Over the years, the journal has become better known, especially internationally, and manuscript submissions have increased substantially. To see the list of the present Editorial Advisory Board Members and their affiliations, please go to page 4 in this journal or the Editorial Advisory Board tab on the website. I would like to recognize them and thank them for their loyal support in reviewing articles, suggesting themed issues, and in many cases, writing articles.

In an effort to increase the credibility of the journal, there were several indexing vehicles added (Table 2). The journal also subscribes to CrossRef. Since August 2013, you will see the DOI number at the top of every article, and article references now contain DOI numbers when available. The journal does have an impact factor, though less than 1, it is such a niche journal that this is still a good showing.

To facilitate the review process, editorial manager software called PeerTrack was put into use starting in November 2013. The system has worked well so far, and review time has been shortened, though there is a still a backlog of articles that have been accepted and are ready for publication. Since the journal is a quarterly publication and there is only space for a maximum of 7-8 articles, this backlog continues to exist. The Editorial Board has limited the scope to exclude articles on dissolution enhancement as this is a formulation issue. Article must have a major focus on dissolution or disintegration testing.

There have been Special Editions as discussed in Greg Martin's article in this journal (1). This has been a successful way to get scientists to write up their work when given an invitation and deadline. There is now an article category called "Technical Note," which is a peer-reviewed article that may be short and at times can be a discussion of new technology. In 1999 there was a Special Edition that was the fifth anniversary issue on the role of dissolution testing, which paid special attention to developments over the first five years of publication of Dissolution Technologies. Again in 2004, a Special Edition for the tenyear anniversary had guest authors discuss the future of dissolution testing from the perspective of FDA, industry, USP, and academia.

As many know, this journal is open-access. This means that there is no charge for viewing the content online. In addition, because the journal gets revenue from advertisers and book sales, the hard copy subscriptions are free in most cases. This open-access journal does not charge authors for publishing, and there is no intention to start this practice. If readers do not want to have the hard copy mailed to them, they can sign up for an e-mail alert when a new issue is posted. 


\section{Table 1. List of Editorial Advisory Board}

\begin{tabular}{l}
\hline Cynthia Brown, Board Chair \\
\hline William Brown \\
\hline Robert Buice, Ph.D. \\
\hline John Crison, Ph.D. \\
\hline Bryan Crist \\
\hline Jennifer Dressman, Ph.D. \\
\hline David Fortunato \\
\hline Nikoletta Fotaki,Ph.D. \\
\hline Vivian Gray \\
\hline Sandra Klein, Ph.D. \\
\hline Johannes Krämer \\
\hline Raimar Löbenberg, Ph.D. \\
\hline Petra Loos, Ph.D. \\
\hline Ruben Lozano, Ph.D. \\
\hline Xujin Lu, Ph.D. \\
\hline Margareth Marques, Ph.D. \\
\hline Gregory P.Martin \\
\hline John W. Mauger,Ph.D \\
\hline Aleksander Mendyk, Ph.D. \\
\hline Rakesh Patel, Ph.D. \\
\hline Dames Polli, Ph.D. \\
\hline Rodian Rohrs, Ph.D. \\
\hline Peter Scott \\
\hline
\end{tabular}

In 2010 Dissolution Technologies had an exhibit booth at the AAPS annual meeting. Since then, there has been a booth at each AAPS Annual meeting. Since 2011 Dissolution Technologies has been present at the Annual CRS meeting, and recently a booth at the EAS annual meeting has been added. The booth presence increases the visibility of Dissolution Technologies so there are more subscribers, scientists who have posters are urged to publish dissolution related articles, and the current issue is provided to the meeting attendees.

There are many people and companies to thank for the support to Dissolution Technologies over the years as article authors, reviewers, support staff, and advertisers. My associate editor, Mary Ann Quarry, has done an excellent job of editing articles and proofing the hard copy with diligence and a fine eye for detail. Mary Ann has been on staff for over 10 years, and her assistance is invaluable.

I also want to mention appreciation for Sandra Larson, my circulation manager (and daughter) who keeps the

\section{Table 2. Dissolution Technologies Is Indexed in:}

\begin{tabular}{l} 
Science Citation Expanded ${ }^{\circledR}$ \\
\hline Journal Citation Reports ${ }^{\circledR} /$ Science Edition \\
\hline International Pharmaceutical Abstracts \\
\hline Chemical Abstracts (CAS) \\
\hline SCOPUS \\
EMBASE \\
CrossRef
\end{tabular}

database and does the bookkeeping for the journal. The webmaster, Mike Larson, is very competent and so very helpful with the website. He instituted the Google search engine, and we have just signed up with Google Analytics and hope to get some valuable information regarding the readership. He posts the current issues and does general editing of the website content-and is very patient with his mother-in-law.

The printer/mailer of Dissolution Technologies is Allen Press located in Lawrence, Kansas. Cindy used them from the beginning, and I have found working with Allen Press in printing the journal and two books a satisfactory relationship.

I want to thank the DT advertisers. As mentioned earlier, the advertisements are the major source of revenue; part of this revenue allows the journal to be mailed free to most of the subscribers. This is a great service to the community of dissolution practitioners. In this issue, there is a commentary (2) from all the long-term vendors. This commentary gives them an opportunity to remind the readers how long they have been in business and how they have served our community. Advertisers have mailed pamphlets and product CDs along with the hard copy of the journal to promote their brands and have also rented or purchased the mailing list. Advertisers are allowed free press releases up to a full page. The readers of Dissolution Technologies want to know who the vendors are and what new products are available. Since dissolution is such a specialized test, the equipment is equally specialized and an important consideration in running the test.

Thanks again to Cindy Brown for Dissolution Technologies. The plan is to keep it going as long as dissolution is practiced in pharmaceutical laboratories.

\section{REFERENCES}

1. Martin, G. Dissolution Technologies' Twentieth Anniversary. Dissolution Technol. 2014, 21 (3), 38-39. DOI: 10.14227/DT210314P38.

2. Gray, V. Celebration of Twenty Years from Dissolution Tester Equipment Manufacturers and Other Providers of Dissolution Related Services. Dissolution Technol. 2014, 21 (3), 29-36. DOI: 10.14227/DT210314P29. 